\title{
POLITIK IDEOLOGI DI BALIK DOMINASI WACANA MAKASSAR KOTA DUNIA (ANALISIS WACANA KRITIS MEDIA)
}

\author{
Oleh : Nasrullah \\ Jurusan Sastra Inggris Universitas Mulawarman \\ Nasrullah.mappatang@gmail.com
}

\section{PENDAHULUAN}

\section{LATAR BELAKANG}

Makassar yang sering dikatakan sebagai pintu gerbang perdagangan Kawasan Timur Indonesia memiliki posisi strategis sebagai jalur lalu lintas perdagangan nasional maupun internasional. Olehnya itu, kota yang menjadi ibukota propinsi Sulawesi Selatan ini menjadi salah satu kota dengan aktivitas perdagangan yang tergolong pesat. Selain itu dengan keberadaan beberapa perguruan tinggi di kota ini, maka dengan sendirinya para pelajar dari berbagai daerah baik dari dalam provinsi Sulawesi Selatan maupun dari luar Sulawesi Selatan ikut menambah hiruk pikuk keramaian kota yang dijuluki kota Anging Mammiri ini. Akan tetapi yang tidak bisa dilupakan dengan berkembangpesatnya kota ini dan banyaknya pendatang yang ada di kota ini adalah penduduk asli ataupun penduduk yang telah lama tinggal di kota ini, dan mayoritas diantara mereka menjadi masyarakat kelas bawah dan mendiami beberapa perkampungan penduduk di tepi sungai - sungai yang membelah kota Makassar. Rata - rata pekerjaan mereka berada di sector informal seperti tukang becak, buruh bangunan lepas, buruh pabrik, nelayan dan beberapa pekerjaan informal lainnya.Bisa dikatakan bahwa rata - rata dari penduduk ini adalah mereka yang memiliki tingkat pendidikan yang rendah.

Keberadaan penduduk asli ini oleh kalangan pemerhati sosial dinamakan sebagai kelompok miskin kota. Kelompok masyarakat dengan tingkat pendidikan rendah, dan dengan perkembangan Makassar yang pesat, sedikit demi sedikit mereka tersisih oleh kerasnya persaingan hidup yang ada. Selain itu arus urbanisasi penduduk yang mencoba mengadu nasib di kota ini menambah jumlah masyarakat pencari nafkah tak berketerampilan dan tak berpendidikan di kota ini. Dan di saat yang bersamaan pemerintah kota Makassar mendeklarasikan diri untuk menjadikan Makassar sebagai “Kota Dunia”. Pernyataan tersebut tidak hanya brand ataupun wacana semata, namun sudah mewujud kepada berbagai kebijakan pembangunan. Dan tidak hanya melahirkan gedung yang megah, tapi juga di sisi lain menggusur perkampungan yang dianggap "kumuh" dan pedagang kaki lima serta para pencari kerang dan nelayan kecil di sepanjang pesisir pantai Makassar dari tempatnya mencari nafkah demi melayani arus modal yang ingin berinvestasi dalam rangka mewujudkan konsep "Makassar Kota Dunia” tersebut.

Dari tahun 2008 sampai Tahun 2025 merupakan rentan waktu pewacanaan dan pelaksanaan konsep "Makassar Kota Dunia” tersebut. Dan di saat bersamaan sampai akhir tahun 2013 kemarin dan sampai hari ini, upaya mewujudkan cita - cita pemerintah Kota Makassar tersebut masih terus berjalan dengan berbagai pro dan kontranya. Baik dari segi 
realisasi dilapangan yang tidak sedikit mengancam masyarakat kelas bawah dalam hal ini "Rakyat Miskin Kota" dari penggusuran dan sengketa lahan dari spekulan tanah maupun dari segi wacana di berbagai media. Selain itu semakin terkikisnya tempat mencari nafkah Rakyat Miskin Kota dengan dalih merusak keindahan, mengganggu ketertiban umum, ataupun karena tempat mereka menjadi lokasi dibangunnya megaproyek desain pemerintah yang bergandengan tangan dengan para pemodal yang dimanjakan karena kepentingan investasi modalnya, namun meminggirkan hak hidup kelompok Rakyat Miskin Kota merupakanpemandangan yang mewarnai sejak didengungkannya brand Makassar ini. Selain pertentangan di lapangan materil tersebut, di lapangan ideologis pun tidak kalah kuatnya.

Peran media massa yang turut memproduksi pemaknaan lewat berita yang tidak sedikit mengagungkan konsep Makassar Kota Dunia ini berhadapan dengan kampanye Aliansi Masyarakat Sipil dan rakyat Miskin kota itu sendiri dengan berbagai media dan metodenya. Peranan media massa inilah yang akan menjadi fokus penelitian ini dalam memproduksi pemaknaan berita. Berita yang tentunya memiliki keberpihakan idologis, cultural dan politik terhadap kelas tertentu yang sesuai dengan kelas yang menjadi dasar kelahirannya sebagai sebuah institusi media dalam kaca mata Fairclough dan Althusser. Berita yang hegemonic dalam rangka menguasai dan mengendalikan kesadaran masyarakat sipil dan rakyat Miskin kota dalam terminology Gramsci.

Penelitian ini akan melihat bagaimana ideology wacana dalam berita online mengenai "wacana Makassar kota Dunia". Asumsi awal dengan pendekatan althusserian, bahwa wacana media massa merupakan basis ideologis superstruktur dari basis material - ekonomi suprastruktur masyarakat. Termasuk masyarakat Sulawesi Selatan, dalam hal ini Makassar. Makassar sebagai kota yang dalam hal ini diasumsikan sebagai konteks material yang memiliki sebuah formasi sosial dinamis sebagaimana sebuah tatanan sosial masyarakat pada umumnya. Formasi sosial yang ada ketika dihubungkan dengan relasi kekuasaan dan ideology dalam kaca mata Marxian dan Althusserian, maka fokus kita akan mengarah kepada bagaimana kelas - kelas dalam masyarakat di kota Makassar saling berinteraksi dari segi ekonomi, budaya, dan politik.

Interaksi dan hubungan yang dimaksud adalah dalam kacamata Marxian dilihat dari bagaimana antar kelas sosial saling berinteraksi atau bertarung satu sama lain. Baik pertarungan kelas yang berlangsung di basis material (infrastruktur) maupun pada basis idologis (suprastruktur) dalam kacamata Althusser. Karena objek yang menjadi fokus penelitian disini adalah wacana dalam media massa yang memberitakan bangunan wacana Makassar kota dunia, maka pertarungan kelas yang menjadi fokus disini adalah pertarungan kelas di level ideologis atau superstruktur dalam oleh kelas borjuis dan kelas proletar dalam terminology Marx dan/atau masyarakat sipil dan masyarakat politik yang memegang kekuasaan dalam terminology Gramsci di Selection of Prison Notebooks-nya. Peneltian ini akan menggunakan pendekatan analisis wacana kritis dan Althusserian untuk melihat bagaimana wacana mewujudkan bangunan ideologis untuk menopang bangunan material dalam hal ini pewujudan Makassar sebagai kota dunia yang secara terang terangan 
mengundang arus investasi dan penanaman modal dan berpotensi meminggirkan masyarakat kelas bawah dalam hal ini Rakyat Miskin Kota.

\section{IDENTIFIKASI MASALAH DAN RUMUSAN MASALAH}

1. Pemberitaan media di Sulsel turut mengonstruksi wacana tentang Makassar kota dunia.

2. Wacana kelas dominan bekerja merepresentasikan kekuasaan dan ideology dominan secara terselubung untuk mendominasi dalam wacana Makassar kota dunia

\section{TUJUAN PENELITIAN}

1.Penelitian ini digunakan untuk melihat bagaimana media mengonstruksi wacana tentang Makassar Kota Dunia.

2. Mengetahui dominasi tersebung secara ideologis terhadap produksi wacana Makassar kota dunia yang dilakukan oleh dua media besar di Makassar ini.

\section{METODE PENELITIAN}

Implikasi metodologis merupakan sinergitas dari asumsi ontologis objek penelitian dengan konsep teoritik yang digunakan untuk melihat dan menganalisa permasalahan yang ada dalam objek yang akan diteliti. Sehingga sinergitas dari asumsi ontologis dengan pisau analisis berupa pendekatan dan/atau teori yang digunakan harus pula berkorelasi dengan metode yang akan digunakan supaya menghasilkan sebuah hasil penelitian yang bisa menjawab permasalahan yang lahir dari objek penelitian yang diteliti.

Metode yang akan digunakan dalam penelitian ini adalah metode deskriptif analisis dengan langkah - langkahnya seperti di bawah ini;

1. Penelitian ini dilakukan dengan mengumpulkan bahan dari beberapa media untuk menjadi objek kajian analisis

2. Data yang dikumpulkan dideskripsikan dengan menggunakan pendekatan analisis wacana kritis Norman Fairclough untuk melihat relasi kekuasaan dan ideology yang menjadi basis wacana media yang memberitakan Makassar Kota Dunia. Kemudian dianalisis dengan menggunakan konsep Analisis wacana Althusserian untuk melihat bagaimana kekuasaan dan ideology kelas dominan bekerja dalam rangka mendominasi kelas yang berada pada posisi subordinat.

\section{LANDASAN TEORI}

Teori yang dipakai untuk melihat objek pada penelitian ini adalah Analisis wacana Kritis Norman Fairclough untuk melihat bagaimana kekuasaan dan ideology pada teks berita yang memuat tema tentang Makassar Kota Dunia. Konsep wacana tentang kekuasaan dan 
ideology yang ada akan mengacu pada konteks kelas yang dilihat dalam perspektif Analisis wacana Althusserian. Dalam wacana Althusserian yang menekankan pada peran ideologis media massa akan mengarahkan kita pada bagaimana wacana yang diproduksi oleh media massa tersebut bersifat hegemonic dalam rangka mendominasi kesadaran kelas yang didominasi. Pemikiran Gramsci akan menjadi rujukan dalam tahapan ini.

\section{Konsep teoritik Analisis Wacana Kritis Norman Fairclough}

Analisis wacana Kritis Norman Fairclough memandang wacana sebagai sebuah praktik politik. Dalam pandangannya Fairclaugh berita di media massa terkhusus di media cetak yang menampilkan teks sebagai sebuah wacana tidaklah memiliki sikap yang netral. Produsen wacana pada media tersebut akan berfokus untuk menyampaikan nilai - nilai ideal dari yang menjadi penggerak media tersebut. Dalam bahasa lain siapa yang mendanai atau mensponsori media tersebut, ke arah situlah nilai ideal dalam pemberitaan itu bermuara. Ia akan memiliki pengaruh ideologis yang kuat, memitoskan hubungan dominasi, dan mendukung pandangan bahasa publik dari kekuasaan yang mendominasi.

Fairclough menganalisa pengaruh wacana dengan menggeledah teks kemudian menghubungkannya dengan struktur sosial yang ada di masyarakat dimana dominasi ideologis dan relasi kuasa secara politis berkorelasi dengan produksi teks wacana yang dihasilkan oleh media massa. Fairclough menempatkan hal tersebut dengan argumentasinya yang mengatakan bahwa:

The third theme is the theorization of power as in part 'ideological / discoursal', the power to shape orders of discourse, to order discursive practices in dominance. Even casual conversation has its conditions of possibility within relations of ideological/ discoursal power.

---- 'Discourse representation in media discourse' contrasts with the preceding theoretical paper in its focus upon linguistic details of texts. On the basis of an analysis of a set of newspaper articles, it suggests tendencies in the representation of discourse ('reported speech') in the media; that the reported discourse is not generally clearly demarcated from the report itself, and that there is generally a focus upon the ideational meaning (the 'content') of the reported discourse and a neglect of its interpersonal meanings and its context. The paper argues that the fine detail of text is in this regard tuned to the social structures and power relations within which the media operate, and has ideological effects in mystifying relations of domination, and sustaining a view of public language and practice as trans- parent. (Fairclough,1995:24-25)

Selanjutnya Norman Fairclough menegaskan bahwa:

'Language and ideology' suggests that the language- ideology relation should be conceptualized within the framework of research on discoursal and sociocultural change. Following Gramsci (Forgacs 1988), the conception of ideology here focuses upon the effects of ideologies rather than questions of truth, and features of texts are seen as ideological in so far as they affect (sustain, undermine) power relations. Ideology is seen as 'located' in both structures (discourse conventions) and events. On the one hand, the conventions drawn upon in actual discursive events, which are structured together within 'orders of discourse' associated with institutions, are 
ideologically invested in particular ways. On the other hand, ideologies are generated and transformed in actual discursive events - the example I refer to is of ideological creativity in a Margaret Thatcher radio interview. An order of discourse may incorporate in Gramscian terms an 'ideological complex', a configuration of ideologies, and both the ideological complex and the order of discourse may be reconstructed in the course of discursive events . (Fairclough,1995:25)

Kekuatan Ideologis dan politis dari wacana melalui medium bahasa yang merepresentasikan sebuah dominasi kekuatan akan sebuah praktik pemaknaan terhadap realitas menjadi penekanan Fairclaough dalam pernyataannya di atas. Struktur social dan relasi kuasa disampaikan dengan sangat baik oleh teks wacana yang disajikan.Disitulah ideology dan kepentingan politis kelompok dominan penguasa merepresentasikan relasi kuasanya terhadap kondisi social yang digambarkannya sesuai dengan agenda ideologis dan politisnya.Transformasi wacana yang dijalankan melalui proses representasi teks media dalam kacamata Fairclough ini mengindikasikan terbentuknya sebuah pemahaman public yang mengacu kepada pemahaman yang dikonstruksi oleh wacana dominan. Efek dari hal tersebut oleh Fairclogh disebutnya sebagai mistifikasi relasi dominasi kekuasaan yang beroperasi melalui teks - teks berita media dalam rangka memproduksi kiblat kebenaran yang tidak lain adalah sebuah upaya melanggengkan agenda politik yang sifatnya ideologis dari proses dominasi yang sedang berlangsung. Fairclough disini mempertegas konsep Gramsci tentang hegemoni yang beroperasi melalui teks - teks media.

Secara skematik Eriyanto dalam buku Analisis Wacana-nya sebagai pengantar analisis teks media membagi analisis wacana dalam tiga dimensi yakni teks, discourse practice, dan sociocultural practice(Eriyanto,2006:286). Pada dimensi teks, teks dianalisis secara linguistik dengan memperhatikan kosa kata, semantic, dan tata kalimat.Ketiga elemen tersebut digunakan untuk melihat bagaimana representasi bekerja secara ideologis, relasi kuasa antara produsen dan audience, dan bagaimana konstruksi identitas dari produsen dan audience serta objek yang ditampilkan dalam teks.Dalam analisis teks ini tema yang menjadi fokus Fairclough adalah representasi, relasi, dan identitas wartawan, khalayak, partisipan dan situasi yang ditampilkan dalam teks.Untuk dimensi discourse practice, Eriyanto menekankan pemahaman tentang bagaimana teks itu diproduksi dan dikonsumsi, serta didistribusikan. Sebagai gambaran, produksi teks antara media massa yang berbasiskan pada industry akan berbeda dengan media komunitas. Konsumsi teks puisi dengan berita juga akan berbeda yang bisa jadi dikonsumsi secara individu dengan berita media massa yang dikonsumsi secara massif oleh public. Begitu juga dengan distribusi teks melalui proses pewacanaan seorang politisi bisa saja melakukan konferensi pers yang bisa memassifkan distribusi teks wacananya melalui peran media massa akan berbeda dengan kelompok pekerja dan petani yang punya metode tersendiri untuk mengorganisir pesan kepada khalayak. Untuk dimensi sociocultural practice ditekankan pada aspek di luar teks yang berkorelasi dengan situasi social, praktik institusi media tersebut dengan kondisi masyarakat, konteks budaya, dan ekonomi politik tertentu yang disederhanakan ke dalam bagian analisis situasional, institusional, dan sosial (Eriyanto,2006:286-288). 
Intertekstualitas pada dimensi sociocultural ini dibutuhkan untuk memperkaya daya analisa kritis kita terhadap teks media yang diasumsikan sebagai hal yang bersifat ideologis, bernuasa dominative dan hegemonic, serta memiliki relasi kuasa dalam praktik pewacanaannya mulai dari produksi teks sampai pada proses distribusinya. Norman Fairclogh menggunakan metode Michael Bakhtin dan Julia Kristeva mengena intertekstualitas ini.Fairclough menyitir penggunaan intertekstualitas Bakhtin dan Kristeva yang digunakan dalam sastra ini ke dalam analisis teks media.Dimana keberadaan teks diasumsikan datang dan dibentuk oleh teks sebelumnya, saling menanggapi, dan salah satu bagian dari tersebut mengantisipasi dengan yang lainnya (Fairclough dalam Eriyanto, 2006:305-306). Jadi intertekstualitas bisa diasosiasikan dengan permainan sepakbola dimana teks berita media merupakan bentukan dan datang dari teks yang ada sebelumnya kemudian ditanggapi, diantisipasi, dan juga bisa dievaluasi, diasimilasi, disuarakan, dan diekspresikan kembali dalam bentuk lain.

\section{Konsep Analisis wacana Althusserian}

Faruk (2002:142) dalam konsep dan analisis wacana Althusserian di buku analisis wacana dari Linguistik sampai Dekonstruksi menafsirkan pengertian wacana menurut Althusser sebagai ideologi dalam praktik.Tak ada ideology tanpa wacana, dan tak ada wacana tanpa ideology.Media dalam hal ini sebagai alat untuk memproduksi wacana merupakan sebuah apparatus ideologis yang bekerja untuk melakukan hegemoni dalam terminology Gramsci.Tak ada kelas yang dapat memegang kekuasaan dalam waktu lama tanpa melakukan hegemoni atas dan dalam ISA (Ideological State Apparatus).Jadi kelas yang bertarung dalam sebuah formasi sosial masyarakat memperebutkan sekaligus menjadikan ISA sebagai situs perjuangan kelas (Faruk, 2002:138). Dengan demikian Negara dalam hal ini yang mewujud ke dalam bentuk struktur pemerintahan yang menjalankan kebijakan atas nama dan untuk rakyat hari ini menurut pahaman Althusser adalah Negara yang dikuasai oleh kelas berkuasa atas kelas kelas yang dikuasai. Dan media massa sebagai salah satu komponen ISA menurut Graeme Burton (2002:40) dalam More than meets the Eye adalah alat untuk memassifkan hegemoni ideology tersebut dalam rangka mengukuhkan dominasi kelas yang berkuasa, dalam hal ini yang menguasai Negara atas rakyat (Althusser), kelas borjuis (Marx).

Sebelumnya Althussr (dalam Faruk, 2002:142) menyimpulkan adanya struktur cermin duplikat dari ideology yang secara simultan menjamin (1) interpelasi individu - individu sebagai subjek - subjek; (2) subjeksinya pada sang subjek; (3) recognisi timbale balik antara subjek-subjek dengan subjek, rekognisi antar subjek, dan akhirnya rekognisi subjek terhadap dirinya sendiri; (4) jaminan absolute bahwa segala sesuatu benar demikian adanya dan jika subjek - subjek mengenali siapa diri mereka, berperilaku sesuai dengan diri mereka itu, segala sesuatu akan menjadi baik - baik saja.

\section{DOMINASI WACANA MAKASSAR KOTA DUNIA DALAM BERITA MEDIA}

Secara umum teks yang menjadi objek analisis disini berkisah tentang rencana besar walikota Makassar menjadikan Makassar sebagai kota dunia. Berita ini dipublish oleh Harian Fajar yang merupakan Koran yang dibawah bendera Jawa Pos Group milik Dahlan Iskan 
yang sekarang menjabat sebagai Menteri BUMN.Akan tetapi versi berita yang menjadi sumber disini diambil dari situs berita Fajar yakni fajar.co.id.Pemberitaan disini mengeksplorasi bagaimana Makassar memiliki potensi untuk menjadi kota dunia. Selain karena fakta sejarah yang dikatakan oleh Walikota Makassar pada waktu itu Ilham Arif Sirajuddin yang menyebut kejayaan Makassar sebagai salah satu pusat perdagangan pada abad 16, juga ditegaskan oleh arsitek Makassar Kota Dunia Danny Pomanto (sekarang menjadi Walikota Makassar) tentang peran Makassar sebagai pintu gerbang Indonesia Timur.

Dalam menganalisa discourse di bawah ini, terutama dari sociocultural practice, akan dilakukan bantuan metode intertekstual untuk lebih memperkaya konteks yang mempengaruhi lahirnya teks media yang mengangkat masalah rencana Makassar menjadi Kota Dunia ini. Pendekatan ekonomi politik, kajian budaya terutama tentang ideology dominan yabg hegemonic akan menjadi konsen pembahasan dalam Bab ini. Hal itu jugalah yang menjadi tujuan dari penulisan hasil penelitian ini.

\section{ANALISIS TEKS}

\section{Representasi}

Representasi berbicara mengenai bagaimana peristiwa, orang, kelompok, situasi, keadaan, atau apapun ditampilkan dan digambarkan dalam teks. Makassar yang menjadi objek pemberitaan disini dengan Ilham sebagai walikotanya direpresentasikan sebagai kota yang memiliki sejarah, posisi strategis, dan potensi yang sangat memungkinkan untuk menjadi kota dunia. Adapun untuk mewujudkan itu, gagasan Ilham sebagai seorang walikota direpresentasikan sebagai gagasan yang pas untuk memajukan kota Makassar yang pernah memiliki kejayaan pada masa lalu, memiliki posisi strategis, dan juga potensi yang hanya membutuhkan usaha untuk mewujudkan Makassar Kota Dunia tersebut yang menjadi Pusat di Kawasan Indonesia Timur.

Kota Makassar berniat mengharumkan lagi bau rempah-rempah di kawasan timur Indonesia ke pasar dunia......, ibu kota Sulawesi Selatan itu mengajukan diri untuk menjadi kota dunia yang menjadi penghubung ke Indonesia Timur. ....Wali Kota Makassar Ilham Arief Sirajuddin menjelaskan, dasar berpikir mengapa Makassar yang harus maju adalah fakta sejarah

\section{.....Karenanya, Makassar butuh ditata dan dibangun untuk memenuhi kebutuhan itu. \\ ...Makassar saat ini sudah punya bandar udara kelas internasional, pelabuhan, hingga pembangunan ruang terbuka dan hotel di sepanjang Pantai Losari.}

Apa yang menjadi kutipan teks di atas merepresentasikan Makassar di bawah kepemimpinan Ilham Arif Sirajuddin telah menyiapkan Infrastruktur pendukungnya. Tinggal membangun infrastruktur pelengkap dan penataan serta pengelolaan sebagaimana Fajar kembali merepresentasikan kesiapan Makassar tersebut dengan tampilan teks: 
Pakar tata kota yang berdomisili di kota tersebut, Danny Pomanto melihat Makassar cukup siap untuk menjadi kota dunia ....

Yang kemudian dibutuhkan adalah dukungan dari pusat.

Selain itu secara akademis ditampilkannya Ekonom Unhas dalam teks berita ini ikut menegaskan bagaimana legitimasi akademik ikut menguatkan Makassar yang direpresentasikan sebagai kota yang sangat memungkinkan menjadi kota bertaraf intrenasional dengan menjadi pemain di percaturan global. Melanjutkan harapan Ilham dan Danny, Hamid Paddu selaku Ekonom Unhas menegaskan bahwa untuk menjadi pusat kemajuan di Indonesia Timur dan menjadi Kota Dunia, dibutuhkan infrastruktur keuangan sebagaimana Fajar merepresentasikannya lewat teks:

Ekonom Universitas Hassanuddin Abdul Hamid Paddu mengatakan, setelah infrastruktur keras, Makassar juga perlu jadi penyedia infrastruktur keuangan.

Representasi Makassar Kota Dunia yang diidamkan seolah di dorong percepatannya dengan tampilan Fajar di atas yang mengkonstruksi teks pemberitaannya seolah tanpa celah dan hambatan sedikitpun dari rakyat Makassar yang selama ini merasakan bagaimana penggusuran dengan mudahnya dilakukan.Berita Fajar di atas benar benar memoles Makassar seolah tanpa cacat sehingga hanya peran pusat dan dukungan politiklah yang menjadi tantangan terwujudnya Makassar Kota Dunia.Sementara pertimbangan bagaimana nasib rakyat Makassar dan kesiapan warga Makassar tidaklah menjadi pertimbangan utama yang ditampilkan dalam teks berita.

Adapun keberadaan orang miskin yang dibendakan melalui teks kemiskinan direpresentasikan hanya sebagai pelengkap indicator terwujudnya kota dunia dengan persyaratan yang sesuai dengan indicator tingkat kemiskinan nasional. Bukan berupaya untuk menyelesaikan masalah pokok lahirnya kemiskinan, akan tetapi justru hanya ingin menyesuaikan agar syarat menjadi Kota Dunia tetap terpenuhi. Representasi terhadap kemiskinan tersebut ditampilkan Fajar sebagai berikut:

Keseluruhan pembangunan tersebut diperlukan untuk menjadikan Makassar kota besar dengan Produk Domestik Regional Bruto (PDRB) Rp100 triliun di 2025 dengan tingkat kemiskinan perkotaan yang sejalan dengan tingkat kemiskinan nasional

Kemiskinan yang terepresentasikan di atas selain untuk melengkapi representasi yang menguatkan Makassar menuju Kota Dunia, juga untuk menciptakan/memapankan mitos bahwa orang miskin hanyalah salah satu penghambat terwujudnya Kota Dunia yang dianggap sudah sangat memungkinkan bagi Makassar.

\section{Relasi}

Reporter dan atau redaksi dari fajar online ini mengidentifikasi dirinya sejalan dengan pemerintah kota Makassar yang mengusung kota dunia. Fajar tidakmenghadirkan warga kota Makassar dalam memberikan penilaiannya tentang konsep Makassar Kota Dunia ini. Hanya Walikota Makassar, Arsitek Makassar 
Kota Dunia, dan Ekonom Unhas yang semuanya sepakat dengan konsep ini yang ditampilkan oleh media Fajar ini. Terutama para korban penggusuran akibat program Makassar Kota Dunia ini sama sekali tidak ditampilkan. Sedangkan hubungan fajar dengan pembaca seolah mengatakan kepada khalayak bahwa Makassar Kota Dunia ini adalah keniscayaan dimana ditandainya dengan orientasi teks yang mendukung argument awal walikota Makassar ini.

Seperti yang fajar tampilkan dalam pemberitaannya;

Kota Makassar berniat mengharumkan lagi bau rempah-rempah di kawasan timur Indonesia ke pasar dunia. Tidak lagi ingin selalu mengandalkan Jakarta, ibu kota Sulawesi Selatan itu mengajukan diri untuk menjadi kota dunia yang menjadi penghubung ke Indonesia Timur.

Wali Kota Makassar Ilham Arief Sirajuddin menjelaskan, dasar berpikir mengapa Makassar yang harus maju adalah fakta sejarah.

"Dilandasi semangat abad ke-16 di mana Makassar menjadi pusat perdagangan keempat di Asia Pasifik, kita sekarang ingin menjadikan Makassar tidak menjadi kota dunia sebagaimana di negara berkembang, tapi bagaimana Makassar sebagai pusat Indonesia Timur," tuturnya.

Fajar disini memberikan perannya yang signifikan dalam memposisikan diri di pihak pemerintah kota Makassar dengan menempatkan Walikota Makassar sebagai subjek yang mengutarakan rencana pembangunannya ke depan dan juga pengagungan Makassar di awal pemberitaan. Judul Makassar Ingin Menduniakan Indonesia Timur mengandung dua unsure yang signifikan yakni pertama keterlibatan Makassar dalam percaturan dunia, kemudian yang kedua menjadi pionir Indonesia Timur. Selanjutnya penegasan dari Walikota Makassar, Arsitek/konseptor Makassar Kota Dunia Danny Pamanto, serta Ekonom Unhas menjadikan posisi Makassar Kota Dunia yang diusung oleh Ilham Arif Sirajuddin sebagai walikota di teks ini semakin menguat dan tak terbantahkan.Dany Pamanto ditampilkan sebagai penegas seperti pada teks di bawah ini:

"Perlu ada dukungan pemerintah pusat.Jangan melihat Makassar sendiri.Makassar harus dibuat menjadi living room Indonesia Timur yang kalau bisa beban pembangunannya dibagi dua. Bagaimana regulasi ini dibuat sehingga mendukung Makassar menjadi pusat perdagangan dan finansial Indonesia Timur, " paparnya. ........Catatan yang dibuat Danny, pemerintah pusat memang perlu menekankan komitmen untuk menjadikan Makassar lebih dari sekedar pintu gerbang ke timur. Pemerintah pusat belum memperlihatkan hal itu dalam Masterplan Percepatan dan Perluasan Pembangunan Ekonomi (MP3EI) meski Makassar sudah dimasukkan sebagai kota penting di koridor empat, lima, dan enam.

Hanya dibutuhkan upaya - upaya untuk mewujudkannya dan selain itu tidak ada hambatan karena suara masyarakat luas Makassar tidak diakomodir oleh Fajar dalam berita ini. Sedangkan untuk legitimasi akademis, pandangan Hamid Paddu; 
"Instrumen keuangan harus dikembangkan di Indonesia Timur sehingga tidak terpusat lagi di Jakarta. Sekarang kan yang sudah ada masih pada lemebaga keuangan dan bank. Ini harus dibuka untuk lebih luas. Tapi ini butuh dukungan politik," cetus Hamid.

Pernyataan tersebut mengindikasikan kebutuhan dan langkah Makassar Kota Dunia jika ingin terwujud. Bukannya menginterupsi, justru memberikan masukan bagaimana itu diwujudkan dengan daya dukung dari sector - sector lain.

\section{Identitas}

Identitas wartawan mengidentifikasi dirinya berada di pihak yang setara dengannarasumber dalam menilai Makassar kota dunia ini. Sedangkan orang miskin yang dibendakan menjadi kemiskinan ditempatkan di posisi yang subordinat dari wartawan dan atau editor Fajar secara penempatan teksnya.

Dalam bayangan Ilham, Makassar harus berguna sebagai hub ekspor maupun penyedia jasa bagi perekonomian Sulawesi, Maluku, hingga Papua.

Karenanya, Makassar butuh ditata dan dibangun untuk memenuhi kebutuhan itu.

Untuk itu, kebutuhan utama yang perlu didukung adalah pembangunan infrastruktur.

Identitas orang miskin hanya dijadikan indicator bagaimana mencapai hasrat Makassar kota dunia dapat dijalankan, sebagaimana teks di bawah ini yang dikutip dari sumber berita:

Keseluruhan pembangunan tersebut diperlukan untuk menjadikan Makassar kota besar dengan Produk Domestik Regional Bruto (PDRB) Rplo0 triliun di 2025 dengan tingkat kemiskinan perkotaan yang sejalan dengan tingkat kemiskinan nasional

Disini posisi wartawan memposisikan diri di atas orang miskin dengan menempatkannya pada posisi yg jadi indicator perbandingan saja tanpa mencoba untuk menampilkan sosok si miskin yang menderita akibat tergusur agenda - agenda Makassar kota dunia.

\section{ANALISIS DISCOURCE PRACTICE}

Produksi teks melibatkan reporter Fajar dan Editor di ruang Redaksi. Selain itu terdiri dari beberapa unsure yang ikut menentukan kebijakan sebagaimana susunan Redaksi yang terdiri dari: Pemimpin Umum, Wakil Pemimpin Umum, Pemimpin Redaksi/Penanggungjawab, Wakil Pemimpin Redaksi/Wakil Penanggungjawab, Redaktur Pelaksana, Koordinator Liputan, Dewan Redaksi, Staf Redaksi, Reporter, Fotografer, Pracetak/Grafis, Teknologi Informasi (Lihat Lampiran 2). Jadi setidaknya ada lima sampai enam tingkatan yang akan dilalui oleh seorang reporter Fajar sampai teks berita yang dihasilkannya dari lapangan menjadi berita yang ditampilkan di situs 
online ini, dan begitupula dengan Koran cetak. Meski secara metodologi, wawancara mendalam di dalam ruang redaksi tidak dilakukan, akan tetapi setidaknya kita bisa mendapatkan gambaran bagaimana sebuah teks berita yang akan menjadi sebuah wacana (discourse) diproduksi untuk membumikan konsep Walikota Makassar tentang Makassar Kota Dunia ini.

Reporter yang mewawancarai tiga narasumber pada berita ini yakni Ilham Arief Sirajuddin selaku walikota, Danny Pomanto selaku arsitek Makassar Kota Dunia, dan Prof.Hamid Paddu selaku dosen Ekonomi Unhas menampilkan hasil wawancaranya dan mengirim ke redaksi yang kemudian akan mengalami penyuntingan sampai pada penentuan content dan framing berita di meja pimpinan redaksi. Selain menyunting dan memposisikan diri, Redaksi Fajar juga akan menambahkan data yang relevan untuk menguatkan penekanan pemberitaan. Hal tersebut terlihat di akhir berita ini yang menampilkan data PRDB Kota Makassar dan targetan PRDB tahun $2025^{1}$ yang akan dicapai. Jadi secara implicit, posisi seorang reporter yang berhadapan langsung oleh narasumber dan bertindak sebagai ujung tombak produksi teks berita yang nanti akan mewujud menjadi wacana di public tidaklah sepenuhnya berdaulat atas berita yang dia hasilkan. Berita yang dia kirimkan ke redaksi akan tetap disaring sampai benar - benar sesuai dengan kehendak kebijakan Dewan Redaksi dan ataupun pemilik media yang memiliki kepentingan atas konstruksi berita yang dihasilkan oleh Fajar mengenai Makassar Kota Dunia ini. Adapun untuk berita online ini, penikmat beritanya akan mengarah kepada audience yang berada pada level menengah ke atas. Dan mereka yang berada di level menengah ke bawah memiliki peluang yang kecil untuk mengkonsumsi teks berita Makassar Kota Dunia yang dihasilkan oleh fajar online ini.

\section{ANALISIS SOCIOCULTURAL PRACTISE}

\section{Situasional}

Makassar kota dunia adalah Visi misi Ilham Arif Sirajuddin ketika mencalonkan diri menjadi walikota untuk periode keduanya. Ditengah agenda pasar bebas dan terbukanya persaingan pasar, Makassar dipoles mengarah ke berbagai jargon yang intinya ingin menggaulkan Makassar dengan percaturan global. Berbagai gedung pencakar langit dibangun, daerah sepanjang pantai barat Makassar sepanjang selat Makassar dipoles jadi tancapan beton dan timbunan timbunan menggunung demi membangun apa yang disebutnya sebagai infrastruktur penyokong Makassar Kota Dunia yang diimpikan oleh Ilham.

Selain itu, sejak tahun 2011-2025 pemerintah menggenjot rancangan pembangunan Indonesia melalui program MP3EI (Master Plan Percepatan Pembangunan Ekonomi Indonesia). Apa yang diagendakan oleh pemerintah pusat ini adalah upaya mempercepat pembangunan Indonesia di segala sector untuk menjadikan Indonesia sebagai kekuatan ekonomi di Asia bahkan di dunia yang disegani. Seperti itulah argumentasi para pejabat pemerintah yang menjadi perancang maupun pelaksana program MP3EI ini.Kondisi tersebut bersua suka dengan posisi strategis Makassar yang selama ini dianggap menjadi Pintu Gerbang dan Penghubung perekonomian di Kawasan Timur Indonesia.

Namun, di pemandangan lain terlihat berbeda. Penggusuran yang marak dilakukan oleh para mafia tanah di Makassar ataupun pemerintah kota dan

\footnotetext{
${ }^{1}$ Lihat Lampiran 1
} 
pemerintah provinsi dimana mega proyek mereka senantiasa membutuhkan lahan. Sepanjang pantai dari Tallo sampai tanjung bunga yang membentang sepanjang pesisir kecamatan tallo sampai Mariso, penggusuran tempat tinggal dan tempat mencari nafkah masyarakat di sekitar area tersebut menjadi tergusur, tergusur oleh apa? Tergusur oleh nafsu mendunia oleh pemerintah yang menjadi boneka pemodal dan pengusaha yang serakah dan tak peduli dengan rakyat kecil yang jumlahnya banyak ${ }^{2}$.

Selain itu kondisi Makassar masihlah menyisakan ketimpangan social yang masih tinggi. Pemukiman yang tidak layak huni dengan mudahnya digusur bukannya ditata oleh pemerintah kota. Privatisasi ruang public juga dan tidak adanya upaya serius dari pemerintah kota untuk meberi ruang kepada kelompok menengah ke bawah untuk memberdayakan diri secara ekonomi dan pendidikan menjadikan ketimpangan semakin terasa. Ditandai dengan maraknya anak usia sekolah bahkan usia belia menumpuk di setia perempatan lampu merah. Angka kriminalpun termasuk tinggi. Baik berupa aksi perampokan , pencopetan, ataupun penipuan lewat berbagai modus begitu marak terjadi akibat tersumbatnya saluran nafkah bagi warga Makassar yang pemerintahnya justru ingin menjadikannya Kota Dunia ${ }^{3}$.

\section{Institusional}

Media Fajar adalah bagian dari Jawa Pos Group yang merupakan milik Dahlan Iskan yang merupakan menteri BUMN Kabinet Indonesia Bersatu Jilid II dibawah pimpinan SBY.Ilham Arif Sirajuddin adalah pimpinan Partai Demokrat Sulsel dan walikota sekarang adalah usungan dari Partai Demokrat.Secara relasional Fajar dan pemerintah kota Makassar saling membutuhkan satu sama lain dalam hal pemberitaan citra pemkot dan ketersediaan informasi dan iklan dari program program pemkot adalah incaran Fajar untuk keberlangsungan bisnisnya.

Ekonomi media yakni iklan, oplah, persaingan antarmedia, dan kepemilikan oleh Alwy Hamu yang merupakan orang dekat Jusuf Kalla dimana Ilham dikenal luas sebagai salah satu orang dekat JK menjadikan hubungan Pemkot dan Fajar akan semakin mesra di bawah nahkoda keduanya. Fajar adalah Koran dengan oplah yang terbesar kelima di luar Jawadan di Makassar sendiri bersaing dengan Tribun Timur yang merupakan milik Aksa Mahmud bos Bosowa Group, ipar JK dan Tribun Timur ini tergabung ke dalam Kompas Gramedia Group. Persaingan dan hubungan erat di sector ekonomi media inilah dalam memperebutkan iklan, akses informasi, dan sumber daya yang lain yang mebuat Fajar harus tetap menjaga hubungan baiknya dengan Pemkot sebagai mitra strategis. Sekaligus mengamankan sektor politik baik politik penguasa terhadap media, maupun politik media kepada public dalam mengontrol pikiran masyarakat tentang pemerintahnya demi kelancaran arus laba dan keberlangsungan bisnis medianya.

\section{Sosial}

\footnotetext{
${ }^{2}$ Disarikan dari data divisi riset dan strategi LAW Unhas, dapat juga dilihat di www.lawunhas.wordpress.com

${ }^{3}$ Buletin Benang Merah terbitan LAW Unhas edisi II 2014
} 
System ekonomi Indonesia yang dinilai sangatlah neoliberal ${ }^{4}$. Hal itupun merambah ke penguasaan frekuensi public dan produksi konten media yang menjadikan public semata sebagai target pasar. Pelibatan Negara sebagai pembuka gerbang sekaligus penjaga setia modal dan korporasi di Indonesia merambah sampai Makassar yang diagung - agungkan sebagai Pintu gerbang dan Pusat Indonesia Timur.

Diperparah lagi dengan System politik Indonesia yang menganut demokrasi liberal ala Amerika menjadikan modal dan media bermain mencari pelipatan keuntungan dalam kontestasi perebutan kursi kekuasaan. Sehingga apa yang ada adalah pemimpin yang dihasilkan adalah pemimpin yang tersandera oleh kepentingan para pemilik modal yang mengusung sang pemimpin ${ }^{5}$. Jadilah modal ini sebagai kuda troya demokrasi sekaligus membonceng media dalam melakukan propaganda terhadap usungannya dan nmerekayasa kesadaran masyarakat sesuai pesanan pemilik modalnya ${ }^{6}$.

Dalam pandangan kritis, penguasaan pada sector ekonomi di era post fordism ini akan berimplikasi pada system budaya dominan ${ }^{7}$. Dengan berkuasanya system kapitalisme Global di Indonesia dengan hubungan mesranya dengan para Kapitalis Birokrat dan Tuan tanah komprador menindas rakyat banyak menjadikan ideology budaya dominan diwarnai oleh mitos - mitos kelas atas atau yang sering dibilangkan sebagai budaya kelas elit yang mencoba dihegemonikan kepada rakyat banyak agar terlena dari kesadaran kelas dan ketertindasannya secara ekonomi politik dan ideology kebudayaan. Gaya hidup modern nan konsumtif menjadikan penguasaan kapitalisme dalam masyarakat Indonesia menjadi langgeng dan pemujaan atas kemegahan pembangunan meski menyisakan utang yang banyak bagi generasi selanjutnya menjadikan kebudayaan kita baik berupa kebudayaan tradisi maupun budaya subsisten dalam ekonomi dan budaya gotong royong dalam ranah social politik menjadi terkikis dan bahkan nyaris punah. Begitupula dengan slogan Makassar Kota Dunia menyimpan ideology dibaliknya dimana modal besar siap menyerbu masuk dan menyingkirkan rakyat banyak yang sudah dilemahkan duluan oleh pemerintah kota Makassar lewat ketidaktersediaan kehidupan yang layak bagi mereka.

Siapa berkuasa dan nilai apa yang dominan di Indonesia saat ini $?^{8} \mathrm{Hal}$ tersebut tidak lepas dari bagaimana Indonesia menceburkan diri ke dalam ekonomi

\footnotetext{
${ }^{4}$ Revrisond Baswir, Mafia Berkeley dan Krisis Ekonomi Indonesia, Terbitan Pustaka Pelajar tahun 2006, Bab 4 Neoliberalisme halaman 77

${ }^{5}$ Disarikan dari Buku Mansour Fakih berjudul Jalan Lain, Manifesto Intelektual Organik, diterbitkan oleh Pustaka Pelajar tahun 2011 pada bagian 3 Globalisasi dan dampaknya halaman 182

${ }^{6}$ Noam Chomsky dalam Politik Kuasa Media dan Manufacturing Consent, Political Economy of mass media ${ }^{7}$ Ibid

8 Disarikan dari bacaan Jurnal Indoprogress edisi II 2012 bagian IV Negara di masa Neoliberalisme halaman 195-213
} 
Kapitalisme di bawah komando IMF, Bank Dunia, dan WTO ${ }^{9}$. Berkuasanya Suharto sejak 1965 sebagai pembuka jalan Kapitalisme berkuasa di Indonesia dan di tahun 2004 lalu SBY terpilih menjadi presiden pertama yang dipilih langsung oleh Rakyat Indonesia membawa Indonesia kepada era baru dalam suhu politik demokrasi liberal dengan memberi ruang kepada MNC dan TNC untuk berkuasa di Indonesia lewat UU Minerba dan Batubara serta UU Penanaman Modal beserta serangkaian UU pembuka kerang investasi dan privatisasi yang lain yang intinya membuka ruang selebar - lebarnya kepada swasta dan asing untuk menguasai sector strategis negeri ini atas nama investasi dan pertumbuhan ekonomi serta ketersediaan lapangan kerja. Begitu pula dengan Makassar Kota Dunia yang mengagungkan mitos - mitos kapitalisme tersebut dan menyingkirkan rakyat banyak yang semakin lemah daya tahan hidupnya di kota - kota besar seluruh Indonesia terkhusus di Makassar.

\section{Intertekstualitas Berita Makassar Kota Dunia}

Dalam berbagai pemberitaan media yang pada tulisan ini berfokus pada pemberitaan online beberapa media di Makassar yang juga tidak lain sebagian besar memiliki Koran cetak kecuali Antara News yang juga dijadikan basis data pada tulisan ini, wacana Makassar Kota Dunia yang mewujud ke dalam program pemerintah pemkot Makassar ini adalah wacana yang sangat booming di kalangan masyarakat. Sebut saja pemberitaan yang ditampilkan oleh Fajar, Tribun Timur, Tempo, Koran Sindo, serta Antara adalah lima dari sekian banyak media yang beroperasi di Ibukota Sulawesi Selatan tersebut. Secara struktur Ekonomi Politik, kepemilikan media Fajar adalah bagian dari Grup Jawa Pos, sedangkan Tribun Timur adalah milik dari grup Kompas, Tempo.co adalah grup media Tempo, sedangkan Koran Sindo adalah bagian dari MNC Group corporation. Sementara itu Antara News adalah bagian dari Kantor Berita Antara.

Keberadaan wacana media yang menampilkan konsep tentang Makassar Kota Dunia tersebut dalam analisa ini akan menggunakan pendekatan Analisis Wacana Kritis Norman Fairlclogh dan Althusser untuk mengungkap bagaimana teks media berperan dalam merepresentasikan dan mengonstruksi wacana dominan kelas penguasa beserta agenda dibalik wacana yang ada tersebut. Wacana Makassar kota dunia yang merupakan program dari walikota sekarang yakni Ilham Arif Sirajuddin sejak 2008 yang kemudian akan dilanjutkan oleh Ramadhan Dani Pamanto-Syamsu Rizal yang tidak lain adalah usungannya pada pilwalkot 2013 lalu. Konsepsi kota global dan prioritas memajukan kota dengan agenda investasi, perdagangan serta pembangunan infrastruktur kelas dunia adalah agenda terbesar dari program yang dinilai prestisius ini (Lihat Pemberitaan fajar.co.id pada lampiran).

Selain itu dalam pemberitaan Tempo, anggaran senilai 48 Triliun untuk pewujudan program ini dinilai sebagai kucuran dana yang membutuhkan sinergitas pusat-daerah untuk membangun infrastruktur serta symbol - symbol bangunan berkelas dunia untuk mencapai

\footnotetext{
${ }^{9}$ Revrisond Baswir menjelaskan secara detail dalam tulisannya di Buku Mafia Berkeley pada bagian 3 yang membahas khusus tentang IMF dan juga skema Neoliberalisme pada bagian berikutnya
} 
gelar Kota Dunia untuk Makassar (Lihat pemberitaan Tempo pada Lampiran). Selanjutnya kearifan local akan dijadikan alat legitimasi untuk mewujudkan ini sebagaimana ditampilkan oleh Sindo melalui berbagai masukan dari pada ilmuwan social, budaya, dan sejarah dalam sebuah seminar yang membahas soal ini beberapa waktu lalu di Makassar oleh Pemkot Makassar (Lihat Berita Sindo pada lampiran). Pelaksana program dalam hal ini adalah walikota Makassar yang dalam waktu dekat akan digantikan oleh pasangan terpilih pilwalkot 2013 lalu diberitakan melalui berbagai programnya yang akan mewujud ke dalam renstra di lapangan nantinya. Teks Berita tersebut ditampilkan oleh Tribun timur dan Antara News (Lihat Pemberitaan tribun timur dan antara news pada lampiran).

Lantas apa sebenarnya yang menjadi persoalan jika keberadaan jargon Makassar Kota Dunia tersebut menjadi sebuah program dari pemerintah Makassar dan kemudian ditampilkan dalam pemberitaan media adalah fokus analisa dari tulisan ini. Norman Fairclough menekankan bahwa pemberitaan media merupakan sebuah selubung struktur social yang berkorelasi dengan relasi kuasa kelompok dominan yang merepresentasikan sebuah fakta menurut konsepsi dominan dari subjek penguasa yang ditampilkan oleh media.Secara struktur social dan ekonomi politik, diketahui secara umum bahwa Indonesia pada hari ini sedang dilanda oleh arus global dan kebijakan ekonomi neoliberal dimana keberadaan investasi dan pembangunan yang mengarah kepada kuasa modal merupakan indicator kemajuan sebuah pemerintahan.Dengan adanya program yang men-jargon pada Makassar Kota Dunia tersebut berkorelasi dengan keberadaan struktur Ekonomi Politik yang sedang berlangsung saat ini di Negeri yang sedang kita tempati ini, terkhusus kota Makassar yang disinyalir sebagai pintu gerbang perekonomian Kawasan Timur Indonesia. Juga kita bisa mengaitkannya dengan program MP3EI (Master Plan Percepatan Pertumbuhan Ekonomi Indonesia) yang dimana indicator keberhasilannya adalah bagaimana pembangunan Infrastruktur penunjang investasi dan akomodasi investasi dapat dimaksimalkan. Dengan demikian logika modal dan perdagangan global yang secara ekonomi politik akan menyingkirkan kelompok lemah dalam hal ini kelas pekerja dan Miskin Kota yang mayoritas menghuni kota Makassar.

\section{Pandangan Analisis Wacana Althusserean sebagai Simpulan dalam Menyingkap Politik Idoelogi dibalik Pemberitaan ”Makassar Kota Dunia” yang marak di Media Massa}

Pendekatan Analisis wacana Althussirian yang menekankan aspek ideology kelas kapitalis dan politik berwacana kelas penguasa dalam hal ini kelas borjuasi kapitalis mengindikasikan bahwa tampilan teks berita kelima media yang menjadi objek data pada tulisan ini mewakili relasi kuasa ideology kelas borjuis kapitalis melalui agenda globalisasi dan neoliberalismenya dalam wujud konsepsi Makassar Kota Dunia ini. Keberadaan Angka 48 Triliun yang ditampilkan Tempo mengindikasikan bahwa kuasa modal akan berbicara banyak dalam program perwujudan Makassar Kota Dunia ini. Adapun keberadaan wacana kearifan local yang ditampilkan oleh Sindo hanyalah sebagai varian lain yang menjadi pemanis untuk berkuasanya logika modal yang akan bekerja dalam pembanguna infrastruktur dan pemenuhan kran investasi di kota yang dianggap memiliki posisi strategis untuk perdagangan Indonesia ini. 
Dengan menggunakan pemikiran Althusser yang dipertegas secara detail oleh Fairlclough dalam menelaah teks media tentang Makassar Kota Dunia ini membawa kita pada asumsi bahwa konsep dan produksi wacana yang dihasilkan oleh Media yang ada di kota Makassar ini tidak lepas dari relasi kuasa dominasi kelas pemodal dalam hal ini borjuis kapitalis dalam mewujudkan dominasi penguasaan modal dan kehidupan warga Makassar melalui penguasaannya akan arah pembangunan dan pengelolaan Makassar ke depan dengan akomodasi dari pemerintah kota. Baik yang masih memerintah sekarang maupun yang akan menggantikannya dalam waktu dekat. Dengan demikian melalui analisis wacana ini dengan menggunakan pandangan kedua tokoh di atas maka dapat dikatakan bahwa wacana, ideology dan blok politik rakyat Makassar yang notabene merupakan warga kelas bawah akan tersingkir atau terdominasi oleh penguasa yang ada dan akan nada nantinya.

Efek dari massifnya pemberitaan media ini juga menurut Fairclough akan menciptakan sebuah mistifikasi dominasi relasi kuasa yang menjadikan konsepsi Makassar Kota Dunia ini sebagai hal yang lumrah dan dibenarkan sebagai hal yang baik - baik saja oleh warga Makassar dan kalangan public secara umum. Sehingga dominasi dan hegemoni ideologi kelas penguasa yang begitu berambisi mewujudkan Makassar Kota Dunia ini dengan mudah akan terealisasi tanpa adanya sebuah perlawanan dari pihak yang merasa dirugikan, terutama warga kelas bawah sebagai objek yang merasakan kebijakan tersebut saat ini dan untukmasa yang akan datang. Wujud formasi social yang sangat kapitalistik inilah yang menjadikan formasi discursive-ideologis yang menurut Althusser menjadi arena dominasi kelas penguasa yang juga sangat kapitalistik.

\section{DAFTAR PUSTAKA}

Althusser, Louis. 2006. Ideology and ideological state Apparatus (Notes Towards an Investigation) edited by Durham dan Kellner, Blackwell Publishing

Aminuddin, dkk.2002.Analisis Wacana dari Linguistik Sampai Dekonstruksi.Yogyakarta:Kanal

Baswir, Revrisond.2006.Mafia Berkeley dan Krisis Ekonomi Indonesia.Yogyakarta:Pustaka Pelajar

Burton, Graeme. 2002 .More than Meets the Eye, An introduction to Media Studies, Arnold Publishers, Great Britain

Chomsky,Noam.2009.Politik Kuasa Media.Yogyakarta:Pinus Publisher

Eriyanto.2012.Analisis Wacana, Pengantar Analisis Teks Media.Yogyakarta:Pustaka Pelajar Fairclough,Norman.1995. Critical discourse Analysis.New York:Longman Publishing Fakih, Mansour.2011. Jalan Lain, Manifesto Intelektual Organik. Yogyakarta:Pustaka Pelajar Gramsci, Antonio. 2013. Selected of Prison Notebooks.Yogyakarta: Pustaka Pelajar 


\section{SUMBER LAIN:}

http://www.fajar.co.id/kotadunia/2873122_6443.html, diakses 22 April 2014, pukul 22.00

www.tempo.co, 23 November 2010 , diakses 22 April 2014 pukul 23.15 WIB

http://www.antara-sulawesiselatan.com/berita/49266/visi-misi-pasangan-dia-mewujudkan-makassarkota-dunia, diakses 23 April 2014, 00.24 WIB

http://www.antara-sulawesiselatan.com/berita/51345/wali-kota-makassar-terpilih-bahas-renstra , diakses 23 April 2013, 00.27 WIB

http://makassar.tribunnews.com/2013/04/12/super-wujudkan-makassar-kota-dunia, diakses 22 April 2014, 23.58 wib WIB

http://www.koran-sindo.com/node/330327, Diakses 22 April 2014 pukul 22.30 WIB

\section{LAMPIRAN 1}

Thu,01 August 2013 | 15:2806:28

\section{Makassar Ingin Menduniakan Indonesia Timur}

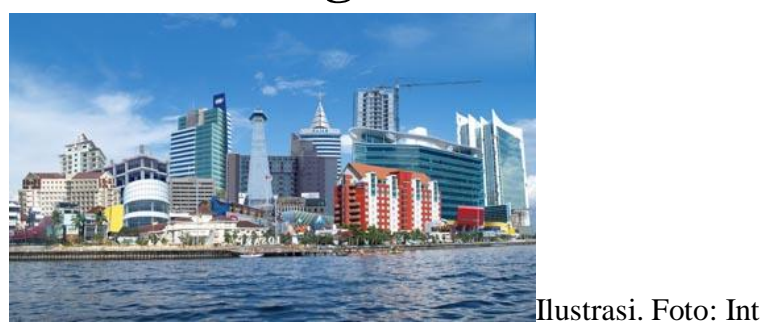

JAKARTA, FAJAR -- Kota Makassar berniat mengharumkan lagi bau rempah-rempah di kawasan timur Indonesia ke pasar dunia. Tidak lagi ingin selalu mengandalkan Jakarta, ibu kota Sulawesi Selatan itu mengajukan diri untuk menjadi kota dunia yang menjadi penghubung ke Indonesia Timur.

Diskusi mengenai peran besar yang diemban Kota Makassar tersebut, ditayangkan Economic Challenge Metro TV, Senin 29 Juli malam lalu.

Wali Kota Makassar Ilham Arief Sirajuddin menjelaskan, dasar berpikir mengapa Makassar yang harus maju adalah fakta sejarah.

"Dilandasi semangat abad ke-16 di mana Makassar menjadi pusat perdagangan keempat di Asia Pasifik, kita sekarang ingin menjadikan Makassar tidak menjadi kota dunia sebagaimana di negara berkembang, tapi bagaimana Makassar sebagai pusat Indonesia Timur," tuturnya.

Dalam bayangan Ilham, Makassar harus berguna sebagai hub ekspor maupun penyedia jasa bagi perekonomian Sulawesi, Maluku, hingga Papua.Karenanya, Makassar butuh ditata dan dibangun untuk memenuhi kebutuhan itu.

Untuk itu, kebutuhan utama yang perlu didukung adalah pembangunan infrastruktur.Ilham menjelaskan, 
Makassar saat ini sudah punya bandar udara kelas internasional, pelabuhan, hingga pembangunan ruang terbuka dan hotel di sepanjang Pantai Losari.

"Sekarang pelabuhan harus dibenahi, ruas jalan ditambah," katanya seraya menambahkan, cetak biru Makassar 2025 saat ini sudah siap, dengan tata ruang yang disesuaikan dengan rencana nasional.

"Perencanaan sudah ada. Sekarang bagaimana saya harus titipkan ini untuk pemimpin masa depan agar pembangunan berkelanjutan."

Pakar tata kota yang berdomisili di kota tersebut, Danny Pomanto melihat Makassar cukup siap untuk menjadi kota dunia melihat pembangunan delapan tahun terakhir. Yang kemudian dibutuhkan adalah dukungan dari pusat.

"Perlu ada dukungan pemerintah pusat.Jangan melihat Makassar sendiri.Makassar harus dibuat menjadi living room Indonesia Timur yang kalau bisa beban pembangunannya dibagi dua.Bagaimana regulasi ini dibuat sehingga mendukung Makassar menjadi pusat perdagangan dan finansial Indonesia Timur," paparnya.

Upaya tersebut, lanjut Danny, akan searah dengan upaya debottlenecking yang didengungkan pemerintah.

Catatan yang dibuat Denny, pemerintah pusat memang perlu menekankan komitmen untuk menjadikan Makassar lebih dari sekedar pintu gerbang ke timur. Pemerintah pusat belum memperlihatkan hal itu dalam Masterplan Percepatan dan Perluasan Pembangunan Ekonomi (MP3EI) meski Makassar sudah dimasukkan sebagai kota penting di koridor empat, lima, dan enam.

"Misalnya hub seaport itu dalam MP3EI ditaruh di Bitung.Padahal, kegiatan hub laut kenyataannya secara informal terpusat di Makassar. Ini melawan anatomi yang sudah terbentuk," cetus Danny.

Padahal, Makassar sudah mencita-citakan Pelabuhan Soekarno-Hatta menjadi pelabuhan ekspor-impor.

Ekonom Universitas Hassanuddin Abdul Hamid Paddu mengatakan, setelah infrastruktur keras, Makassar juga perlu jadi penyedia infrastruktur keuangan.

"Instrumen keuangan harus dikembangkan di Indonesia Timur sehingga tidak terpusat lagi di Jakarta. Sekarang kan yang sudah ada masih pada lemebaga keuangan dan bank. Ini harus dibuka untuk lebih luas. Tapi ini butuh dukungan politik," cetus Hamid.

Keseluruhan pembangunan tersebut diperlukan untuk menjadikan Makassar kota besar dengan Produk Domestik Regional Bruto (PDRB) Rp100 triliun di 2025 dengan tingkat kemiskinan perkotaan yang sejalan dengan tingkat kemiskinan nasional. Sebagai catatan, PDRB kota tersebut pada 2011 adalah Rp36,73 triliun. (int/ist)

Sumber; http://www.fajar.co.id/kotadunia/2873122_6443.html, diakses 22 April 2014, pukul 22.00 